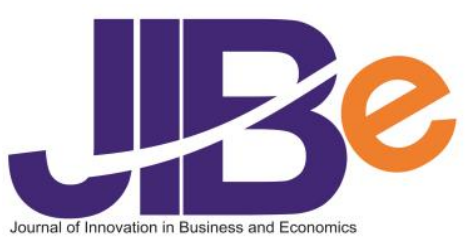

\title{
Poverty Alleviation Through Social Capital in Coastal Areas: Pariaman Coastal Case
} Neng Kamarni ${ }^{1}$, Muslich Anshori ${ }^{2}$, Raditya Sukmana ${ }^{3}$

\section{Postgraduate School, Universitas Airlangga, Surabaya,} Indonesia ${ }^{1}$

Faculty of Economics and Business, Universitas Airlangga, Surabaya, Indonesia ${ }^{2,3}$

\begin{abstract}
This study aimes to provide an overview of the importance of social capital in poverty alleviation in Pariaman coastal area. The research was a survey research conducted in Padang Pariaman District, sample was conducted purposively sampling with 100 fishermen households as a sample. The result revelead that institution and culture variables get good categories while trust and participation variables are categorized as poor. The institution is one of four variables which has a significant correlation with welfare while the others are not significant. Trust and participation variables not have a significant correlation because they get poor category, but the interesting case even though the culture variable which gets a positive category but does not correlate significantly with the welfare. Although only institution variable which has a significant correlation with welfare, in general social capital has a positive impact on poverty alleviation in Pariaman Distric.
\end{abstract}

Keywords: Social capital; institution, trust; culture; participation

\section{Introduction}

In general, the poverty which inherent in the lives of fishermen communities has become a factual situation in coastal areas of Indonesia (Humaedi, 2012). Even farmers, including fishermen in Southeast Asia, are generally subsistence with the economic principles of safety first (Scott, 1994), where the lives of fishermen are very close to their subsistence boundaries. According to Imron (2003), compared to other community groups in the agricultural sector, fishermen especially traditional fishermen can be classified as the poorest social stratum, although it cannot be said that all fishermen are poor.

The image of fisherman poverty is actually an irony, considering that Indonesia has a vast sea area, wider than the land area. Within the sea area there are also various resources that have high economic potential, which should be utilized to ensure the welfare of the lives of fishermen and their families. Mussadun and Nurpratiwi (2016), stated that some of the causes of poverty of fishermen are natural factors, namely season and coastal damage. Structural factors is caused by unbalanced income, the selling price of fish catches is low. Cultural factors, namely the behavior of consumptive fishermen, they easily owe money to moneylenders and are difficult to save. Based on research conducted by Goso and Anwar (2017), the poverty that occurs in traditional fishermen is caused by three influential factors, namely: 1) human resources quality factor; 2) economic factors; and 3) institutional factors.

Sociologically, the characteristics of fishermen are different from farmers. As well, the resource and geographical characteristics between regions are varied. Central Bureau of Statistics of Indonesia in 2017 released a poverty rate of 27.77 million people or 10.64 percent of the total population of around 245 million. From these data, there were around 7.87 million poor coastal communities and 2.2 million very poor coastal populations in all regions of Indonesia or around 25.14 percent of the total poor population (Badan Pusat Statistik, 2018). In fishing communities, poverty and other life challenges are cycles of social economic events that almost always repeat every year. According to Mmom and Chukwu-Okeah (2011) in addition to the problems of the marine coastal environment, poverty is a major issue that occurs due to complex factors.

The problems faced by fishermen are very complicated and diverse. They cannot be solved independently by fishermen. Therefore solving these difficulties must be addressed together through fishing groups. Groups of fishers, traders and fish processors are interdependent business actors in the fisheries

${ }^{1}$ E-mail: nengkamarni@gmail.com

2E-mail: slich@feb.unair.ac.id

${ }^{3}$ E-mail: raditya-s@feb.unair.ac.id 
sector who can unite to empower fishing communities through the development of social networks along with the increasing social capital in the form of social networks of fishermen groups. Increasing fishermen's social capital is carried out by internal empowerment of fishermen groups and by involving external structures of fishermen groups. The aim is that these fishermen groups have more power to overcome the problems faced in their activities, thus providing a positive impact on their welfare.

Research by Morris (1998) stated that social capital has positive effect on social welfare, although Morris in his research did not include culture and institutions as social capital variables. Fukuyama (2002), assures that with strong social capital, the community will unite power and energy in development to deal with poverty. Fukuyama continued that the main cause of failure of economic development that occurred in various parts of the world was the non-functioning of social capital component which ideally grew in the midst of society. But the different result conducted by Cleaver's (2004), the social capital does not have a real impact to reduce poverty and improve welfare. This finding is due to research focusing on policies to strengthen institutions and eliminate culture and community participation as the main core of social capital.

The problem of fishing poverty is also experienced by fishermen in the coastal area of Padang Pariaman Distric. The good news, since 2016 poverty in Pariaman tends to decline (Badan Pusat Statistik, 2018). This shows that the program for reducing poverty in Pariaman Distric is quite successful, whether social capital is one of the factors in decreasing the poverty level in Pariaman Distric is an interesting thing to discuss. Using the initial premise that social capital has an effect on poverty alleviation, this study develops a social capital model which includes institution, culture, trust, and participation as a variables and has the aim of knowing the relationship between social capital and poverty alleviation in Pariaman coastal area.

\section{Literature Review Social Capital}

Putnam (1995), defines social capital as a resource owned by society in the form of norms or values that facilitate and build cooperation through a harmonious and conducive network of interaction and communication. Social capital becomes the glue for every individual, in the form of norms, trust and networks, so that mutual cooperation occurs to achieve common goals. According to Hasbullah (2006), social capital is the sum of resources, actual or virtual (implied) that develops in an individual or group of individuals because of the ability to have a network that can be sustained in a relationship that has been instituted based on knowledge and understanding of reciprocity.

Previous research, such as Dasgupta (1997) revealed that social capital has a role in economic development. Even Colleta (2000) stated an explanation of the importance of social capital in overcoming conflicts and managing post-conflict development. Grootaert (1999), stated that the increasing stock of social capital, also increased public welfare (net benefits) as a result of the increasing number of transactions, joint ventures, output, quality of life, environmental quality and other facilities enjoyed by the population. Social capital has been found to have a large impact on the income and welfare of the poor (Sundaram, et. al., 2011). Social capital increases the potential of the community in several ways (Putnam, 1995). This promotes business networks; share prospects, services; joint ventures, faster information flow and better transactions. Social capital creates local economic prosperity (Putnam, 1993; Fukuyama, 1995; Coleman, 1988 \& 1990).

Furthermore, social capital can reduce poverty through micro and macro channels by influencing the movement of information that benefits the poor and by increasing the growth and redistribution of income at the national level (Grooteart and Bastelaer, 2002). The structural component of social capital refers to social network relationships among actors within a given system. Relationships among individuals with similar demographic characteristics, such as family members, neighbors, and close friends, are referred to as "bonding" social capital; relationships among individuals that differ in these characteristics but live in proximity to each other are referred to as "bridging" social capital (Grootaert et al., 2004).

Hasbullah (2006) in the concept of community-based development, states that the success of development can be seen from various community capital, namely: human capital (personal abilities such as education, knowledge, health, expertise and others); Natural capital (natural resources such as forest resources, water resources, marine waters, minerals, etc.); Economic capital produced (in the form of developing economic and financial assets, as well as other assets; social capital (including norms / values, beliefs, and networks). According to Putnam (1995), Fukuyama (1995), differences in mutual trust are factors that cause differences in development in an area. In addition, trust is also a component of social capital that can increase people's access to welfare resources (Grootaert, 2001). Social capital has proven to play an important role in promoting trust and co-operation among fishermen, and can reduce the 'fishing race' (Grafton, 2005). Meanwhile in India, Sekhar (2007) found that the existence of networks and trust 
within and among groups of fishermen facilitated the creation and maintenance of locally designed designs. Nenadovic and Epstein (2016) found that social capital plays a role in the participation of fishermen in governance $n$ multi-level governance. They state that the effects of various types of social capital vary in various types of governance activities. By combining statistical models with qualitative interviews, it appears that the low level of participation in multi-level fisheries governance arrangements is related to the social and historical context of the process of public participation in Mexico. Grootaert and Van Bastelaer (2002) identify two important dimensions of social capital: measuring from micro to macro and sequences from theory to structural.

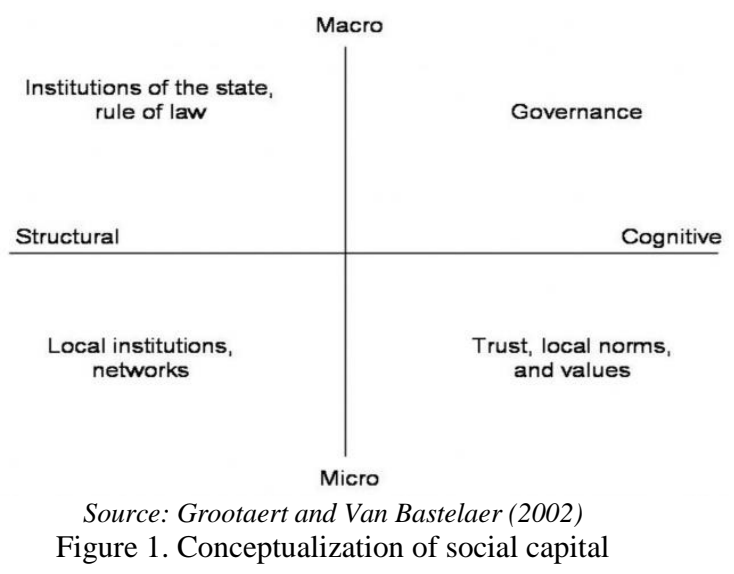

Figure 1 illustrates a conceptualization of social capital developed by Grootaert and Van Bastelaer which divides social capital into two levels: macro and micro. Macro levels refer to State and government institutions, while micro levels refer to local institutional networks, trusts, cultural norms and values both structurally and cognitively. Thus, an in-depth research is needed on empowering poor fishermen households with social capital and social networks that are owned, which is in accordance with the characteristics of resources, socio-culture and the environment so that poverty alleviation models can be obtained through social capital in the community.

\section{Poverty}

According to the World Bank (2005), poverty is defined as a form of derivation in welfare and deprivation of freedom to achieve something in one's life. Diversity in formulating views on poverty shows that poverty is a multidimensional phenomenon. Related to the role of government, poverty generally occurs by two main things: first, market failure, where poverty is caused by workers who get wages that are below the standard of decent living needs (KHL) to meet basic needs (clothing, food, health education). Second, Political Failure, where the political economic structure and policies implemented cause a distortion in the delivery of the interests of the poor which causes uncertainty in the direction of economic development. In the statistical data released by Central Bureau of Statistics of Indonesia, the concept of poverty refers to the ability of a person or household to fulfill basic needs which are formulated as a person's inability to be measured in economic terms, where poverty often changes due to many factors causing poverty, including: low education levels, lazy to work, limited employment, limited capital, family expenses.

\section{Poverty in Coastal Area}

The conditions experienced by fishermen in coastal area are certainly worrying, because they are the spearhead of fisheries management in Indonesia. The rate of population growth that continues to increase causes the land become narrower. Therefore, working as a fisherman is considered to be a hope in the future. For this reason, in the future, the community is expected to gradually shift its economic activities towards the sea. According to Imron (2003, 2011), the problem of limited capital, knowledge, expertise, use of fisheries technology and excessive fishing is often stated as a cause of poverty or a low increase in welfare in fishing communities.

The results of research conducted by Hamdani and Wulandari (2013) on the poverty factor of traditional fishermen in Kedungringin Village, Muncar Subdistrict revealed several findings as follows: 1) quality of Human Resources, low levels of education lead to low productivity. Low productivity will affect low income; 2) alternative work, because in reality the work as a fisherman is work that depends on natural 
conditions (sea) in providing its resources; 3 ) the habits of fishermen, or cultures that pay less attention to their future needs, which means that every time they get an abundant catch or more, they will immediately expend or spend their money; 4) capital ownership, is one of the main factors in business development, as a result they cannot increase production both in terms of quantity and quality, which results in low income received; 5) the technology used is still traditional, the equipment used is a wooden boat, some use outboard motors, some use sails instead of outboard motors; 6) the role of economic institutions, the absence of economic institutions or fishing association institutions that are in charge of protecting needs, and distributing catches, and facilitating the needs of traditional fishermen.

\section{Research Method}

This research was a survey research conducted in Padang Pariaman District. The selection of research locations was conducted purposively with the consideration that the district included coastal areas that had a high percentage of poor households (9.89\%) in West Sumatra. The sample in this study is 100 fisherman households in Padang Pariaman Distric, West Sumatra. Indicators of coastal community social capital consist of the following four indicators: a) institution; b) culture; c) trust; and d) participation (Grootaert and Narayan, 2004; Putnam, 1995; Woolcock, 2001). The data analysis technique used is descriptive analysis, achievement level of Trash Coverage Ratio (TCR) respondents, final achievement level in the form of a percentage that can be given a good statement with an achievement level of $>50 \%$ accumulating good social capital (Arikunto, 2002). Analysis of relationships between dependent and independent variables are used to determine whether there is a relationship between welfare variables and social capital variables.

This study uses the premise that poverty alleviation directly proportional to increasing welfare (Deaton, 2016; Tsui, 2002). The structural model describes the relationship of household expenditure to various household assets including social capital:

$$
L n E i=\alpha+\beta S C_{i}+\gamma H C_{i}+\delta O C_{i}+\sigma Z+u_{i}
$$

Where $E_{i}$ is household expenditure (i) per capita; $S C i$ is household assets to sosial capital; $H C_{i}$ is household assets to human capital; $O C_{i}$ is household assets to other aset (land); $\mathrm{Z}$ is household characteristics/number of household members; and $u_{i}$ is error.

\section{Result and Discussion}

Based on data processing, we present the results of four social capital variables, the following are also described regarding the relationship of social capital with welfare and the relationship of each variable of social capital to welfare.

\section{Institution}

Unity reflected in an institution is a manifestation of the development of community empowerment. Community empowerment can be seen from the extent to which group members can work together effectively in developing and maintaining a close network of relationships among fellow citizens. Institutional social capital is basically a resource in the form of economic benefits that can be obtained by a person through his participation in social relations networks. Variable indicators of institution measured is: a) the existence, participation and activeness of the family towards household groups/unions, such as: farmers Group, cooperatives, Julo-Julo (rotating savings), communal Quran recitation, youth/sports; b) institution encourages family economy; c) the most followed union; and d) intensity of group meetings conducted per month.

The most common form of union is the Julo-Julo. The benefits of Julo-julo union groups for participants are business savings and loans, distribution of crops and partnerships such as marriage and death. Institutions function as a trigger for the economy of fishermen families where they can participate in economic activities. The existence of an institution will provide greater benefits if many things can be obtained. A community group has as many ways as possible to show its empowerment, because communities without capacity will lose meaning as a community and open opportunities for the emergence of various negative, apathetic, ignorance and poverty conditions. Based on Table 1, it can be seen that the dimensions of institutions in Padang Pariaman distric get a good category. 
Table 1. Result of institution variable indicators

\begin{tabular}{lcc}
\hline \multicolumn{1}{c}{ Variable } & Result & Category \\
\hline Form of activity in institutions & $70,07 \%$ & Good \\
Groups/institutions that are often followed & $71,77 \%$ & Good \\
Number of groups/institutions that drive the family economy & $78,23 \%$ & Good \\
Meeting intensity per month & $73,47 \%$ & Good \\
Level of institution & $\mathbf{7 3 , 3 8 \%}$ & Good \\
\hline
\end{tabular}

\section{Culture}

Tradition and culture are essential supporting factors in the development process, where it can be used as one of the development capital called social capital. Tradition is regarded as the soul that determines the death of human life. Based on Table 2, dimensions of culture get a good category. Moreover, Padang Pariaman community's belief concerning on the role of tradition toward life system is quite strong. Thus, almost everyone attends religious celebrations enthusiastically. Here, the indicators of special variables measured are: a) participation in wedding celebrations; b) ceremonies of death; c) religious ceremonies (Maulid of Prophet and Isra' Mi'raj); d) restrictions on traditions; e) Family relations; f) sanctions for customary violations. The purpose of respondents' participation in traditional and cultural traditions is to improve worship in the form of infaq (charity) as a sign of gratitude to Allah SWT which is usually used for mosque building improvement and also increasing bond among Muslims in the area.

Table 2. Result of culture variable indicators

\begin{tabular}{lcc}
\hline \multicolumn{1}{c}{ Variable } & Result & Category \\
\hline Participation in marriage ceremonies & $98,64 \%$ & Good \\
Participation in traditional ceremonies of death & $100 \%$ & Good \\
Participation in religious ceremonies & $98,30 \%$ & Good \\
Obedience to customary restrictions & $95,58 \%$ & Good \\
Good Relationship & $87,41 \%$ & Good \\
Indigenous Customs Sanctions & $68,03 \%$ & Good \\
Level of culture & $\mathbf{4 8 , 2 3 \%}$ & Poor \\
\hline
\end{tabular}

\section{Trust}

The existence of community leaders was recognized and generally highly respected by the local community. Community figures were needed in order to motivate the people to work hard in improving their welfare and participating in development. It showed the vital contributions of these figures in people's lives in various aspects, especially social and cultural. Indicators of the trust variable are: a) the role of ninik mamak (the keepers of heritage and tradition) in the family; b) the role of the ulama as a community leader; c) the role of the leader or local community leader (RT leader/Datuak/community leader); d) the role of government officials in the provision of public facilities and infrastructure, (e) Local safety conditions.

The indicator of the social trust capital as shown at Table 3. It shows a level of trust that is poor with $48.23 \%$ of achievement. It means that the community generally states that social capital in the form of trust is lacking towards fellow leaders and governments in carrying out the development process, because clarity and transparency in the process does not satisfy the community.

Table 3. Result of trust variable indicators

\begin{tabular}{lcc}
\hline \multicolumn{1}{c}{ Variable } & Result & Category \\
\hline The role of ninik mamak in family & $49,66 \%$ & Poor \\
Clerical role/function & $46,60 \%$ & Poor \\
The role of local community leaders (Datuak) & $50,00 \%$ & Poor \\
Role of government (Nagari apparatus) & $48,30 \%$ & Poor \\
Environmental security & $46,60 \%$ & Poor \\
Level of trust & $\mathbf{4 8 , 2 3 \%}$ & Poor \\
\hline
\end{tabular}

\section{Participation}

Community participation is needed in development, both moral and material participation. Community participation in development activities is influenced by the willingness, ability and opportunities of the community. The ability of the community to participate is also influenced by the level of welfare. Participation analyzed in this study are: a) family participation in community meetings; b) family participation in other collaborations in the local environment; c) participation in assisting 
government projects in the local area; d) dominant decision making from the leader; and e) participation in caring for and maintaining the cleanliness and comfort of public facilities.

Community participation in mutual cooperation has begun to be lacking, as well as community participation in assisting government projects, leaders in taking policies are very dominant. The participation of the people in the deliberations is very lacking, but the participation of the community in maintaining public facilities is quite good. Based on Table 4, it was shown that in general the level of community participation is poor. This situation meant that community participation in deliberations and other social activities had diminished.

Table 4. Result of participation variable indicators

\begin{tabular}{lcc}
\hline \multicolumn{1}{c}{ Variable } & Result & Category \\
\hline Participation in deliberation & 46,94 & Poor \\
Participation in mutual cooperation & 50,00 & Poor \\
Participation helps government projects & $53,06 \%$ & Good \\
Role of Community leaders & $42,86 \%$ & Poor \\
Participation in maintaining public facilities & $56,80 \%$ & Good \\
Level of participation & $\mathbf{4 9 , 9 3 \%}$ & Poor \\
\hline
\end{tabular}

\section{Level of Social Capital}

Based on the results achieved on the indicators of each variable of social capital as shown at Table 5 , it can be obtained the level of social capital of the coastal communities in Padang Pariaman Regency is good. This shows that if not all indicators have good categories, level of social capital in Padang Pariaman distric can still be categorized as good.

Table 5. Result of social capital variables

\begin{tabular}{lcc}
\hline \multicolumn{1}{c}{ Variable } & Result & Category \\
\hline Institution & $73,38 \%$ & Good \\
Culture & $91,33 \%$ & Good \\
Trust & $48,23 \%$ & Poor \\
Participation & $49,93 \%$ & Poor \\
Level of social capital & $\mathbf{7 6 , 9 2 \%}$ & Good \\
\hline
\end{tabular}

\section{Social Capital and Community Welfare}

Regression analysis was conducted to determine how effective the influence of social capital variables, human capital variables, land ownership variables and household characteristics variables on public welfare. Expenditure of household per capita was as a dependent variable. Independent variables consist of social capital (institutional/unity, customs, trust, participation), human capital (education), land ownership and family characteristics (number of family members). The regression results as shown as Table 6 obtained an adjusted $R^{2}$ value of 0.481 which meant that $48.1 \%$ of the independent variables were able to explain the dependent variable. Or in other words, $48.1 \%$ of the variable social capital, human capital, land and number of household members could explain the level of expenditure per capita (welfare) of coastal communities, the remaining $51.9 \%$ was explained by other factors outside the model used.

Table 6. Dependent regression estimation on household welfare

\begin{tabular}{llccc}
\hline \multicolumn{1}{c}{ Model } & \multicolumn{1}{c}{ B } & Standar Error & T & Sig \\
\hline Constant & 0,643 & 0,099 & 6,489 & 0,000 \\
SC & 0,032 & 0,018 & 1,754 & 0,083 \\
HC & 0,018 & 0,015 & 1,191 & 0,237 \\
OC & 0,027 & 0,017 & 1,588 & 0,116 \\
Z & $-0,070$ & 0,010 & $-6,717$ & 0,000 \\
\hline Number of observations & 98 & & & \\
R Adjusted & 0,481 & & & \\
R-squared & 0,502 & & & \\
F-statistic & 23,460 & & & \\
\hline
\end{tabular}

The estimation results in the form of structural equations can be written as follows:

$$
\text { Ln } E=0,643+0,032 S C+0,018 H C+0,0270 C-0,070 Z
$$


The results above showed that social capital, human capital and land ownership had a positive effect on household welfare while household characteristics had a negative effect. With a coefficient of 0.032 , it meant that if there was an increase in social capital of $1 \%$, houshould welfare would increase by $3.2 \%$. Although it was not a high value, the increase in social capital that affects the welfare of the community must be fostered and become a strength in the community to achieve prosperity and wealth for the coastal communities in the existing institutional empowerment. This meant that social capital had a significant effect on the welfare of fishermen communities. For this reason, to find out whether there was a relationship between the welfare expenditure variable and the variable of social capital cross tabulation has been done. This analysis was completed to achieve the third research objectively, namely to see the relationship between social capital and community welfare.

Based on Table 7 there was a significant relationship between institutions and welfare. A strong social bond in the community will provide a sense of confidence and solid effort to improve their welfare. The results of this study concluded that groups of fishermen should be improved in terms of the number of members and frequency of meetings, so that the objective of improving the development and welfare of fishermen communities can be felt by the community fairly and correctly. There was a insignificant relationship between culture and welfare. The kinship system based on blood ties according to the maternal line, not supported the improvement of community welfare during this objective bond.

Trust, There was no significant relationship between trust and participation with the welfare of the fishermen community. Trust in the government as a provider of facilities and infrastructure must be created because it will greatly affect the smoothness of the development process. The need of trust that emerges from the community certainly makes sense because the public can see which programs are unfair so they can cause distrust to the government. Therefore, there is a great necessity for participation and honesty from both the government and the community to achieve the desired development. The welfare of the fishermen community can be improved through community participation in regional development. The participation can be carried out by the community both in the planning process; for example in deliberation by giving ideas or suggestions to the government and informal leaders; in the implementation stage of development by contributing energy and materials; and in the maintenance phase of development because it is beneficial for the smooth running of economic activities.

Table 7. Correlation betwen variable social capital and community welfare

\begin{tabular}{cccccc}
\hline $\begin{array}{c}\text { Dependent } \\
\text { Variable }\end{array}$ & $\begin{array}{c}\text { Independent } \\
\text { Variable }\end{array}$ & Chi-Squre test & Df & Chi-Square Table & Category \\
\hline & Institution & 49,546 & 26 & 38,885 & Significant \\
Community & Culture & 39,126 & 13 & 22,362 & Not Significant \\
Welfare & Trust & 10,204 & 13 & 22,362 & Not Significant \\
(expenditure) & Participation & 18,578 & 13 & 22,362 & Not Significant \\
\hline
\end{tabular}

The results of this study were consistent with the findings of Grootaert (2004) related to social capital in Indonesia, especially the household welfare model, where the structural model stated that social capital was an input which together with human and physical capital can form a household production function. The results of data processing showed a positive relationship between social capital and household welfare, where fisherman households with high social capital had a high level of expenditure per capita, as a consequence of increasing all assets. This meant that if the community wanted to increase social capital higher it would have an impact on the improvement of their welfare, as well as the willingness to increase education and land ownership, which meant improving family quality and family income, this increase would also affect the improvement of community welfare.

Trust in all elements of society which was characterized by the increasing quality of community institutions was needed to improve the welfare of poor fishermen communities. It could be seen here that, if culture could be preserved and included in the development process, the social impact that arisen was an increase in welfare through various participation and ties in society (Woolcock and Narayan, 2000). Putnam (1995) also stated that social capital referred to the essence of social organizations, such as trust, culture, and social networks that enabled community members to implement their participation in working together effectively and efficiently to achieve shared goals, so that they were able to affect productivity individually or in groups.

This research was also in line with the research conducted by Morris (1998) entitled, but he did not include cultural and institutional elements in his research. The research state that the social capital 
owned by a country's society influenced the country's ability to reduce poverty. Morris' research focused on poverty at the state level in India. In his paper, Morris answered the hypothesis: are countries with greater social capital more successful in reducing poverty? According to him, poverty did not only have an impact on the lack of physical capital and human capital, but social capital was also a determinant of poverty.

However, this was slightly different from Cleaver's (2004) study where according to him the focus of policy was politically neutral and not socialized on strengthening the lives of associations and the participation of the poor could not lead to greater inclusion, or significant poverty reduction. The similarity with this study was that the role of the government was needed with the social capital of the community to reduce poverty. The results of this study were also similar to Daryanto (2004) which stated that the role of social capital in economic development was not as important as other economic infrastructure. Therefore, efforts must always be made to strengthen community socio-economic institutions as social capital in development.

This study concluded that in general, the social capital of coastal communities in Pariaman was at a good level. Results achieved from indicators of institutional variables were good. That was also supported by testing the hypothesis that the correlation between community institution and welfare was significant. This implies that informal institutions such as cooperatives, fisherman groups and others must be optimized and of course this is related to the values of trust and participation. However, the factor of trust in leaders, both for the government and for informal leaders and fellow community members, was in an unfavorable condition. The findings in this study must be a correction in Pariaman Distric, because trust and public participation in development will produce positive results. Triangular collaboration between government, community leaders and citizens will make a higher sense of ownership (Borjas, 2010; Newman, Barnes, Sullivan, \& Knops, 2004).

Cultural variable indicators are at a good level. Although, the Pariaman community has an inadequate standard of living but still upholds its culture, this study reveals by testing the hypothesis that the correlation between culture and welfare is not significant. This needs to be an important note that a strong culture should be a trigger for optimizing welfare. Steensland (2006) stated that culture is the basis of ideology which should have many constitutional roles in improving welfare. Linking the phenomena in Pariaman Distric and Steensland's opinion can be simply stated that constitutionally and formally a welfare improvement program would be better if it accommodates local culture. The research shows that the Pariaman Distric community is very high in the value of customs so that poverty reduction programs through improved welfare will run well. It will also allow that development is not only capitalist oriented but upholds equality (Castells, Himanen, Castells, \& Himanen, 2011).

\section{Conclusions, suggestions and limitations}

Based on the results of the research that has been done, the poverty alleviation model through social capital in coastal areas is recommended in the form of the development of local economic institutions Furthermore, the model of local economic institutions must be strengthened, so that they can empower communities according to local cultural customs. The empowerment process is more oriented towards the growth of group awareness of rights and obligations. Institutional simplification is needed to support the development of business in coastal communities. The characteristics of empowerment are characterized by the presence of local values and rules in the institutional system that give meaning to the improvement of the bottom fishermen's economy.

Because of the four variables of social capital that are categorized as good only variable institutions, in fact this study cannot yet be ascertained regarding the relationship between culture, trust and participation even though many studies show that all variables of social capital, especially trusts and participation have a positive impact on improvement welfare.

\section{Acknowledgments}

We would like to thank the fishermen community in Padang Pariaman District for being willing to answer the questionnaire. We also thank the Community Research and Development Institute of Andalas University for providing assistance, so that this research can contribute to others.

\section{References}

Arikunto, S. (2002). Prosedur penelitian suatu pendekatan praktek. Jakarta: PT. Rineka Cipta

Badan Pusat Statistik. (2018). Statistik kesejahteraan rakyat Kabupaten Pariaman 2018. Padang Pariaman. Retrieved from 
https://padangpariamankab.bps.go.id/publication/2018/12/28/cb0fc76bce32824059d342fc/statisti k-kesejahteraan-rakyat-kabupaten-padang-pariaman-2018.html

Borjas, G. J. (2010). Welfare reform and immigrant participation in welfare programs. International Migration Review. https://doi.org/10.1111/j.1747-7379.2002.tb00119.x

Castells, M., Himanen, P., Castells, M., \& Himanen, P. (2011). The power of identity. In The Information Society and the Welfare State. https://doi.org/10.1093/acprof:oso/9780199256990.003.0006

Cleaver, F. (2005). The inequality of social capital and the reproduction of chronic poverty. World Development Journal, 33(6), 893-906

Coleman, J. S. (1988). Social capital in the creation of human capital. The American Journal of Sociology 94(1), 95-120

Coleman, J.S. (1990). Foundation of social theory. Cambridge, Mass: Harvard University Press. England

Colleta, Nat J., dan Michelle LC. (2000). Violent conflict and the transformation of social capital. Washinton DC. World Bank

Daryanto, Arief. (2004). Penguatan kelembagaan sosial ekonomi masyarakat sebagai modal sosial pembangunan. Agrimedia, 9(1)

Dasgupta, P. (1997). Social capital and economic performance. Washinton DC: The World Bank

Deaton, A. (2016). Measuring and understanding behavior, welfare, and poverty. American Economic Review, 106(6), 1221-43. https://doi.org/10.1257/aer.106.6.1221

Fukuyama, F. (1995). Trust: the social values and the creation of prosperity. New York: Free Press

Fukuyama, F. (2002). Social capital and development: the coming agenda. SAIS Review, 22(1), 23-37

Goso dan Anwar, Suhardi M. (2017). Kemiskinan nelayan tradisional serta dampaknya terhadap perkembangan kumuh. Jurnal Manajemen, 03(01)

Grafton, R. Quentin. (2005). Social capital and fisheries governance. Ocean \& Coastal Management 48, 753-766. Elsevier Ltd. All rights reserved. https://www.researchgate.net/publication /245123797_Social_capital_and_fisheries_governance

Grootaert, C. (1999). Social capital, household walfare and poverty in Indonesia. Social Development Department. Washington DC: World Bank

Grootaert, C. (2001). Social capital: the missing link. The World Bank. Social Capital Initiative. Working Paper. no.3. Washington DC: World Bank

Grootaert, C., and T. Van Bastelear. (2002). The role of social capital in development: an empirical assesment. New York: Cambridge University Press

Grootaert, C., Narayan, D., Nyhan, V., Woolcock, J.M. (2004). Measuring social capital: an integrated questionnaire. 18. Washington D.C: World Bank Publications

Hamdani, Haris., Wulandari, Kusuma. (2013). Faktor penyebab kemiskinan nelayan tradisional. Repository univ. negeri Jember. http://repository.unej.ac.id/handle/123456789/58737

Hasbullah, J. (2006). Sosial kapital: menuju keunggulan budaya manusia indonesia. Jakarta: MR-United Press

Humaedi, M. Alie. (2012). Kemiskinan nelayan: studi kasus penyebab eksternal dan upaya revitalisasi tradisi pengentasannya di Kaliori, Rembang, Jawa Tengah. Jurnal Sosek KP, 7(2)

Imron, Masyhuri. (2003). Nelayan dan kemiskinan. Jurnal Masyarakat dan Budaya, 5(1), 63-82

Imron, Masyhuri. (2011). Nelayan dan kemiskinan. Jurnal Masyarakat dan Budaya, 13(2), 57-82

Knack, Stephen. (1999). Social capital, growth and poverty: a survey of crosscountry evidence. Social Capital Initiative Working Paper No. 7. World Bank

Kusumaatmadja, S. (1996). Empowering coastal communities. Conservation Indonesia

Mmom, P.C., and Chukwu-Okeah, G.O. (2011). Factors and processes of coastal zone development in nigeria: a review research. Journal of Environmental and Earth Sciences. 3(6): 625-632,

Morris, M. (1998) Social capital and poverty in India, IDS Working Paper 61. Brighton. IDS

Mussadun dan Putri Nurpratiwi. (2016). Kajian penyebab kemiskinan masyarakat nelayan di kampung tambak lorok. Jurnal Perencanaan Wilayah dan Kota. Journal of Regional and City Planning. 27( 1), 49-67. doi: 10.5614/jrcp.2016.27.1.5

Nenadovic, M., Epstein, G. (2016). The relationship of social capital and fishers' participation in multilevel governance arrangements. Environmental Science \& Policy. 61, 77-86

Newman, J., Barnes, M., Sullivan, H., \& Knops, A. (2004). Public participation and collaborative governance. Journal of Social Policy. https://doi.org/10.1017/s0047279403007499

Putnam, R. (1993). Making democracy work: civic traditions in modern Italy. Princeton, NJ. Princeton University Press

Putnam, R. (1995). The prosperous community - social capital and public life. American Prospect. Washington DC: World Bank 
Scot, James C. (1994). Moral ekonomi petani. Jakarta: LP3ES

Sekhar, N.U. (2007). Social capital and fisheries management: the case of Chilika Lake in India. Environ. Manage. 39, 497-505

Steensland, B. (2006). Cultural categories and the American welfare state: the case of guaranteed income policy. American Journal of Sociology. https://doi.org/10.1086/499508.

Sundaram, K., Sabesh Manikan, M., And Premkumar, J. (2011). Social capital formation and poverty alleviation: a development strategy. Anjac Journal Of Humanities And Social Sciences. Issn : 0976-4216. 2(2), 1-6

Tsui, K. Y. (2002). Multidimensional poverty indices. Social choice and welfare. https://doi.org/10.1007/s355-002-8326-3

Woolcock, Michael. (2001). Microenterprise and social capital: A framework for theory, research, and policy. The Journal of Socio-Economics, Elsevier, 30(2)

Woolcock, M., and Narayan, D. (2000). Social capital: implications for development theory, research, and policy. The World Bank Research Observer, 15(2), 225-49 